\title{
Antibody Negative Autoimmune Encephalitis: A Case Report
}

\section{Encefalite Autoimune Sem Anticorpo Identificado: Um Relato de Caso}

\author{
Carolina SEQUEIRA $\triangle^{1}$, Pedro LOPES ${ }^{2}$ \\ Acta Med Port 2021 May;34(5):378-382 - https://doi.org/10.20344/amp.13793
}

\begin{abstract}
Encephalitis is characterized by inflammation of the brain. Literature describes autoimmune as one of the most common aetiology of non-infectious encephalitis. Given the similarities in clinical, imagological and laboratory findings with viral encephalitis and due to the wide variety of clinical features, the diagnosis is rather challenging and therefore physicians need an increased clinical suspicion to make the correct diagnosis. We report a case of a 35-year-old male with no past medical history that presented with two episodes of autoimmune encephalitis in a 6-month period. Despite having the typical clinical presentation and imagological findings consistent with autoimmune encephalitis, this case had negative results for antibodies, which delayed the diagnosis. It is essential to highlight the importance of considering the hypothesis of autoimmune aetiology on the differential diagnosis of all patients presenting with clinical and magnetic resonance imaging results suggestive of probable encephalitis, regardless of the negative antibodies results. This case clearly depicts the difficulties of diagnosing and treating an autoimmune encephalitis. The main goal of this case report is to increase awareness towards early diagnosis to promptly implement a specific treatment that has proven to improve the outcome and prognosis. Keywords: Autoantibodies; Encephalitis/diagnosis; Encephalitis/diagnostic imaging; Immunotherapy
\end{abstract}

\section{RESUMO}

A encefalite é caracterizada por inflamação cerebral. A literatura descreve a etiologia autoimune como uma das causas mais frequentes de encefalite não infeciosa. Dadas as semelhanças dos resultados laboratoriais e imagiológicos com a encefalite viral, e devido a uma extensa variedade de manifestações clínicas, o diagnóstico é desafiante, pelo que os médicos precisam de maior suspeita clínica realizarem um diagnóstico correto. Relatamos o caso de um indivíduo de 35 anos, do sexo masculino, sem antecedentes pessoais de relevo, que apresentou dois episódios de encefalite autoimune num período de seis meses. Não obstante uma apresentação clínica e imagiológica típica de encefalite autoimune, o doente apresentava resultados negativos para anticorpos, o que atrasou o diagnóstico. É importante considerar a hipótese de etiologia autoimune no diagnóstico diferencial de todos os pacientes que apresentem sintomas clínicos ou resultados de ressonância magnética nuclear sugestivos de provável encefalite, independentemente da presença ou ausência de anticorpos. Este caso retrata claramente as dificuldades de diagnóstico e tratamento de uma encefalite autoimune. $\mathrm{O}$ principal objetivo deste relato de caso é salientar a importância do diagnóstico precoce, que permite implementar rapidamente uma terapêutica específica, e demonstrou melhorar o prognóstico e suavizar as consequências da doença.

Palavras-chave: Autoanticorpos; Encefalite/diagnóstico; Encefalite/diagnóstico por imagem; Imunoterapia

\section{INTRODUCTION}

Encephalitis is characterized by inflammation of the brain. The literature describes autoimmune encephalitis as one of the most common types of non-infectious encephalitis (data from northern Europe shows that autoimmune encephalitis comprises almost $20 \%$ of all cases of encephalitis). ${ }^{1}$ The most common form of autoimmune encephalitis (AIE) is the type associated with antibodies against the $\mathrm{N}$-methyl-D-aspartate receptor (NMDAR). A study showed that the frequency of this AIE surpassed the frequency of any individual viral cause of encephalitis in young individuals. ${ }^{2}$ Encephalitis characterized by antibodies against leucine-rich, glioma-inactivated 1 (LGI1) is the second most frequent $\mathrm{AlE}^{3}$

AIE may present a range of clinical features including behavioural changes, impaired memory and cognition, psychiatric symptoms, involuntary movements, altered level of consciousness and seizures. Tumours (paraneoplastic) and infections (parainfectious) are frequent triggers of encephalitis. ${ }^{1,4}$
Because of the similarities in the clinical, imaging and laboratory findings with viral encephalitis, the diagnosis of AIE is rather challenging and physicians require increased awareness and clinical acumen to make the correct diagnosis.

AIE was not described until 2007 because of the lack of specific clinical symptoms, laboratory, and magnetic resonance imaging (MRI) results. ${ }^{5}$ When these three parameters are combined, as shown in this case report, the diagnosis of definite AIE can be made, enabling specific therapeutic interventions that if performed at an early stage can significantly improve the outcome. ${ }^{6}$

It is important to acknowledge that patients with AIE may present seronegative cerebrospinal fluid (CSF) and therefore antibody testing is not pathognomonic.

\section{CASE PRESENTATION}

A 35-year-old healthy male, without any significant past medical history presented at the emergency department

1. Medical School. University of Azores. Ponta Delgada. Azores. Portugal.

2. Department of Neurology. Hospital do Divino Espírito Santo. Ponta Delgada. Azores. Portugal.

$\triangle$ Autor correspondente: Carolina Sequeira. carolinasequeira7@gmail.com

Recebido: 25 de março de 2020 - Aceite: 21 de julho de 2020 - First published: 31 de dezembro de 2020 - Online issue published: 03 de maio de 2021 Copyright @ Ordem dos Médicos 2021 
(ED) in January 2019 with behaviour disturbances in the previous five days and speech disturbances in the previous twenty-four hours. There was a suspicion that he had a seizure before coming to the ED. No sphincter incontinence or tongue biting was noticed. In the previous five days, he had been experiencing periods of confusion, sweating, and fainting sensation from which he spontaneously recovered. There was no prior history of seizures, loss of consciousness, or drug use. Simultaneously, he had an unintentional weight loss of $10 \mathrm{~kg}$ in eight months, anorexia, and vomiting.

Physical examination was normal. On neurological examination, he was awake and presented global aphasia (non-fluent speech, he was unable to repeat words or to follow commands), without any other focal neurologic deficits. There were no meningeal signs. Brain computed tomography (CT) was normal. The electroencephalography (EEG) revealed a probable complex partial status epilepticus (frequent left frontotemporal paroxysmal activity). The MRI showed a hyperintense signal on T2-weighted/FLAIR on the medial left temporal lobe (Fig. 1).

CSF showed pleocytosis (47 cells) with mononuclear predominance and elevated proteins (67 mg/dL). The suspicion of a seizure combined with the MRI hyperintense signal on the left temporal lobe was suggestive of herpes simplex encephalitis (HSE). ${ }^{7}$

He was first treated with phenytoin 750 mg IV for reversal of status epilepticus and then started a 21-day cycle of acyclovir $750 \mathrm{mg} 8 / 8$ hours for presumed HSE. The microbiological study of CSF was unremarkable [polymerase chain reaction (PCR) with both negative serology and bacteriological study - HSV-1, HSV-2, HHV-3, Epstein-Barr virus, cytomegalovirus, HHV-6, HHV-7, HHV-8 negative]. Lumbar puncture was not repeated, but lumbar puncture (LP) was performed three days after onset of symptoms. Blood cultures were also negative. He experienced considerable improvement with medication (recovery of normal behaviour and speech) and besides experiencing persecutory delusions while in the hospital, he was released with sporadic speech disorder and without full recovery of cognitive functions. There was a reversal of the imaging changes after treatment.

In July, six months later, he presented in the ED with behavioural and speech changes associated with right hemiparesis in the past 24 hours. His wife mentioned episodes of mental confusion and speech changes since his previous hospitalization. He also showed sudden impairment of consciousness (not reactive to stimuli), right arm clonic movements, and oculocephalic deviation to the right. He received antiepileptic treatment with slight improvement. The EEG was consistent with a complex partial status epilepticus (left temporal paroxysmal activity). Since the status epilepticus was refractory to the antiepileptic medication administered in the ED, he was transferred to the intensive care unit (ICU).

The brain CT showed a hypodensity in the left frontoparietal region. The MRI showed a hyperintense T2/Flair signal in the left frontoparietal and occipital region (Fig. 2). The lumbar puncture performed on the same day of the hospitalization showed CSF with mildly elevated proteins $(71 \mathrm{mg} /$ $\mathrm{dL}$ ), mononuclear cells (25 cells) negative bacteriological examination, negative serologies, and negative cytology for neoplastic cells. The LP was repeated and showed clear and colourless CSF with mononuclear cells (seven cells)
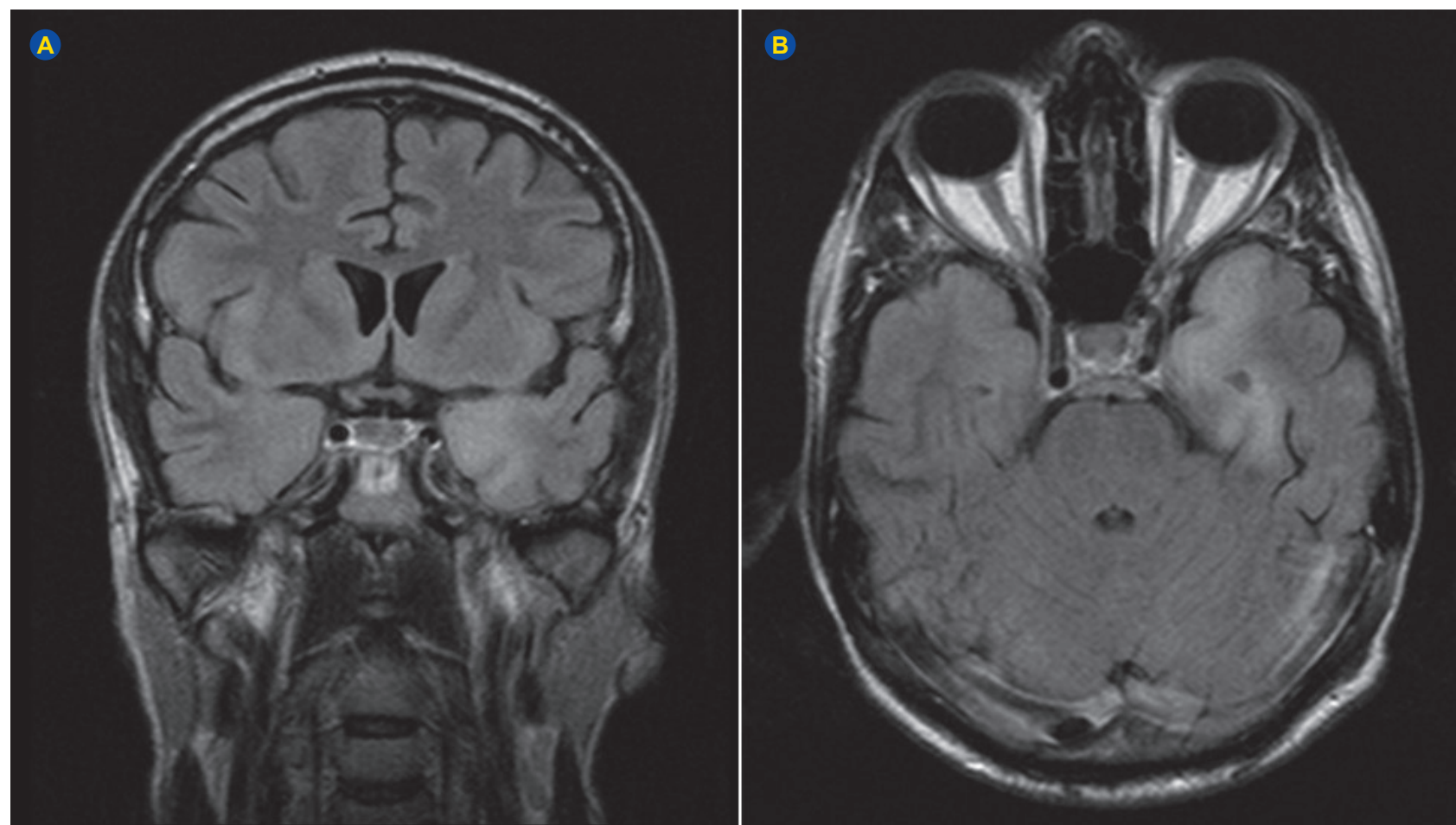

Figure 1 - MRI in February 2019 showed hyperintense signal on T2/FLAIR on the medial left temporal lobe in coronal and axial planes, respectively 

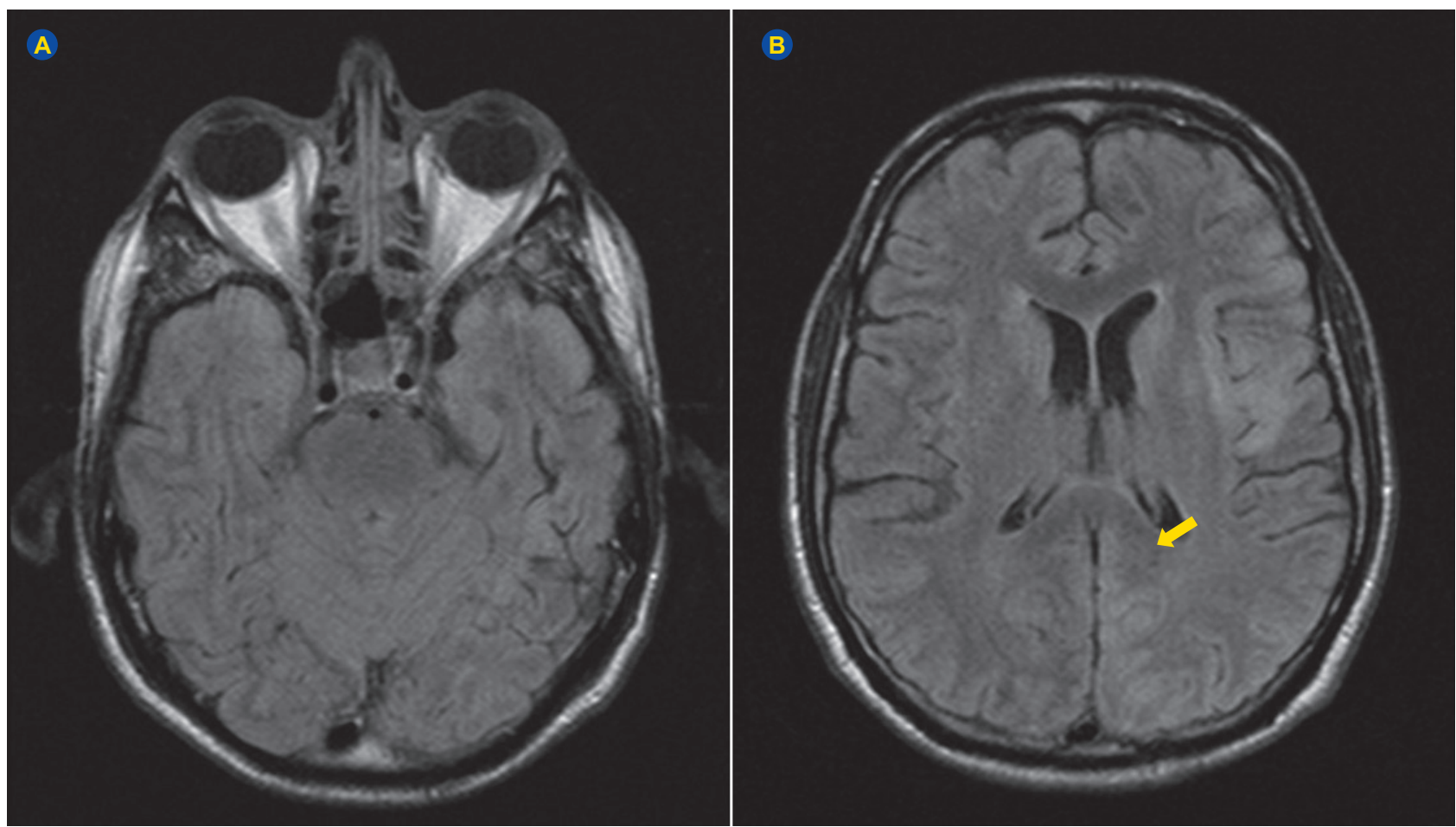

Figure 2 - MRI in July 2019 showed no changes on the previous lesion site (medial left temporal lobe) and showed hyperintense T2/ FLAIR signal in the left frontoparietal and occipital region

and proteins $(0.7 \mathrm{mg} / \mathrm{dL})$, negative serology, bacteriological, and mycological examination. The autoimmune study was negative for anti VGKC, anti-NMDAR, anti-GABAa-R, antiGABAb-R, anti-LGI1, anti- Ma2/Ta, anti-GAD, anti-MAG, anti-Hu and anti- CV2 (immunoblotting and indirect immunofluorescence assay) The diagnostic study in blood culture, urine culture and CSF (PCR) was negative for HSV-1, $H S V-2, H H V-3$, Epstein-Barr virus, cytomegalovirus, HHV6, HHV-7, HHV-8, Enterovirus, Treponema pallidum, HBV, HIV, HTLV, Mycobacterium tuberculosis, Borrelia burgdorferi, tick-borne encephalitis virus (TBEV), Anaplasma phagocytophilum, Ehrlichia chaffeensis/ Ehrlichia muris, human polyomavirus $2(\mathrm{JC})$, polyomavirus BK.

To exclude paraneoplastic causes, a thoracoabdominal pelvic CT scan was performed, with no relevant alterations.

In the ICU he was treated first with a 5-day cycle of high-dose methylprednisolone with a progressive reduction in oral dose associated with a 5-day cycle of immunoglobulin. Simultaneously, he also received a 21-day cycle of acyclovir. He was also treated for a urinary tract infection with amoxicillin and clavulanic acid. He progressively showed some slight improvements in speech and motor functions (ability to follow commands, articulate words, and phrases, improved spatial and self-orientation), with successful treatment of the complex partial status epilepticus. The patient was released in August with antiepileptic medication (levetiracetam, lacosamide, and clobazam) and periodic appointments to assess the mental status and investigate a possible paraneoplastic cause.

On a follow-up clinic in November, although maintaining normal speech and motor functions, he had a clear limita- tion in time, spatial, and self-orientation and showed considerable memory loss with implications in daily life activities. He presented a score of five in the Montreal Cognitive Assessment (MoCA).

\section{DISCUSSION}

This case presents the challenges of diagnosing AIE, since the patient, despite having the typical clinical presentation and imaging findings consistent with AIE, had negative results for antibodies in blood and CSF. Such cases can be misdiagnosed as viral encephalitis. This case report highlights the importance of considering the hypothesis of autoimmune aetiology on the differential diagnosis of all patients presenting with clinical and MRI results suggestive of probable encephalitis regardless of the negative antibody results. Confirmatory antibody testing should be required, but a negative result does not exclude the diagnosis, especially if other possible causes are excluded. The diagnostic criteria for the different types of AIE were published by Graus et al in 2016.

The hypothesis of autoimmune encephalitis after herpes simplex encephalitis (post-herpetic anti-NMDA encephalitis) should be considered. In fact, a prospective observational study showed that $27 \%$ of patients present with AIE after HSE. These patients developed neuronal antibodies $(100 \%)$, usually within two months after treatment of HSE. ${ }^{8,9}$

Therefore, the clinical findings do not completely substantiate this hypothesis as the results for infection by herpesviruses were negative and there were no antibodies for NMDA receptors or neuronal antigens in the CSF. Therefore, this case, and according to the criteria mentioned 

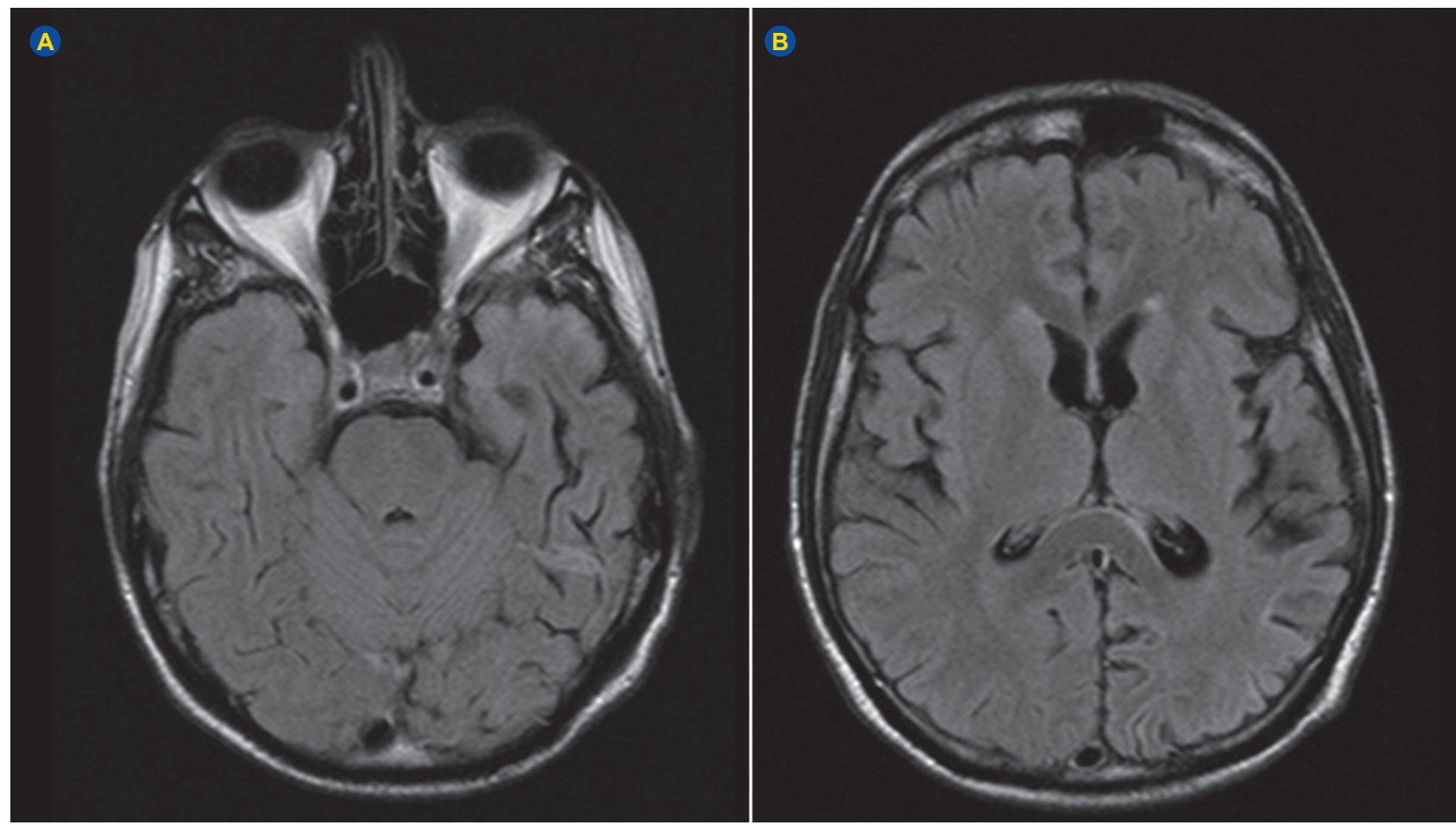

Figure 3 - MRI in August 2019 showed reversal of imaging changes with increased peripheral cortical sulci, probably due to post encephalitis brain atrophy

Table 1 - Diagnostic criteria for negative-antibody probable encephalitis

1. Rapid progression (less than 3 months) of working memory deficits, altered mental state or psychiatric symptoms;

2. Exclusion of known syndromes of autoimmune encephalitis (e.g. ADEM typical limbic encephalitis)

3. Absence of antibodies in serum and CSF, and at least two of the following criteria:

- MRI findings suggestive of autoimmune encephalitis

- CSF pleocytosis or CSF-specific oligoclonal bands or elevated CSF IgG index

- Brain biopsy showing inflammatory infiltrates and excluding other causes

4. Exclusion of alternative etiologies

Only if all of the four criteria have been met, diagnosis can be made

ADEM: acute disseminated encephalomyelitis; MRI: magnetic resonance imaging; CSF: cerebrospinal fluid

above, presents a probable diagnosis of antibody negative AIE. ${ }^{10}$ Noteworthy, this is the best available diagnosis concerning this case, and is not a definitive one.

This case report presents limitations, particularly the fact that not all commercially available antibodies were tested (for example anti-RI, anti-Yo, anti-CASPR2, anti-AMPA) and the screening in cells/tissues samples would be necessary for the definitive diagnosis of antibody negative autoimmune encephalitis.

Currently, the guidelines for diagnosis suggest that a complete antibody panel (intracellular, surface antigen and ion channels) should be done if there is a suspicion of AIE. ${ }^{11}$

Treatment for probable encephalitis is frequently given empirically prior to the results. In this case, acyclovir was given empirically for presumed HSE. The same reasoning can be used, prior to antibody results, with probable AIE, because clinical presentation and treatment response of antibody negative cases does not differ significantly from definitive AIE. Therefore, in suspected patients of AIE based on probable diagnosis, starting first line therapy, which consists of methylprednisolone, IVIG and/or plasmapheresis (there is no strong evidence of a difference in efficacy between IVIG and plasmapheresis), is recommended. First line immunotherapy can be given sequentially if no improvement is shown. ${ }^{6,12}$ In the absence of response, second line therapy should be started with rituximab or cyclophosphamide. ${ }^{6,12}$ The treatment should not be delayed since the evidence suggests early immunotherapy is associated with favourable outcomes and better prognosis. ${ }^{1,11,12}$

\section{PROTECTION OF HUMANS AND ANIMALS}

The authors declare that the procedures were followed according to the regulations established by the Clinical Research and Ethics Committee and to the 2013 Helsinki Declaration of the World Medical Association.

\section{DATA CONFIDENTIALITY}

The authors declare having followed the protocols in use at their working center regarding patients' data publication. 


\section{PATIENT CONSENT}

Obtained.

\section{COMPETING INTERESTS}

The authors have declared that no competing interests exist.

\section{REFERENCES}

1. Dutra LA, Abrantes F, Toso FF, Pedroso JL, Barsottini OG, Hoftberger R. Autoimmune encephalitis: a review of diagnosis and treatment. Arq Neuropsiquiatr. 2018;76:41-9.

2. Gable MS, Sheriff H, Dalmau J, Tilley DH, Glaser CA. The frequency of autoimmune $\mathrm{N}$-methyl-D-aspartate receptor encephalitis surpasses that of individual viral etiologies in young individuals enrolled in the California Encephalitis Project. Clin Infect Dis. 2012;54:899-904.

3. Van Sonderen A, Petit-Pedrol M, Dalmau J, Titulaer MJ. The value of LGI1, Caspr2 and voltage-gated potassium channel antibodies in encephalitis. Nat Rev Neurol. 2017;13:290-301.

4. Dalmau J, Graus F. Antibody-mediated encephalitis. N Engl J Med. 2016;378:840-51.

5. Day GS, High SM, Cot B, Tang-Wai DF. Anti-NMDA-receptor encephalitis: case report and literature review of an under-recognized condition. J Gen Intern Med. 2011;26:811-6.

6. Hermetter C, Fazekas F, Hochmeister S. Systematic review: syndromes, early diagnosis, and treatment in autoimmune encephalitis. Front Neurol. 2018;9:706.

\section{FUNDING SOURCES}

This research received no specific grant from any funding agency in the public, commercial, or not-for-profit sectors.

7. Whitley RJ. Herpes simplex encephalitis: adolescents and adults. Antiviral Res. 2006;71:141-8.

8. Armangue T, Moris G, Cantarín-Extremera V, Conde CE, Rostasy K, Erro ME, et al. Autoimmune post-herpes simplex encephalitis of adults and teenagers. Neurology. 2015;85:1736-43.

9. Armangue $T$, Spatola $M$, Vlagea $A$, Mattozzi $S$, Cárceles-Cordon M, Martinez-Heras E, et al. Frequency, symptoms, risk factors, and outcomes of autoimmune encephalitis after herpes simplex encephalitis: a prospective observational study and retrospective analysis. Lancet Neurol. 2018;17:760-72.

10. Graus F, Titulaer MJ, Balu R, Benseler S, Bien CG, Cellucci T, et al. A clinical approach to diagnosis of autoimmune encephalitis. Lancet Neurol. 2016;15:391-404.

11. Pradhan S, Das A, Das A, Mulmuley M. Antibody negative autoimmune encephalitis- Does it differ from definite one?. Ann Indian Acad Neurol. 2019;22:401-8.

12. Lancaster $\mathrm{E}$. The diagnosis and treatment of autoimmune encephalitis. J Clin Neurol. 2016;12:1-13.

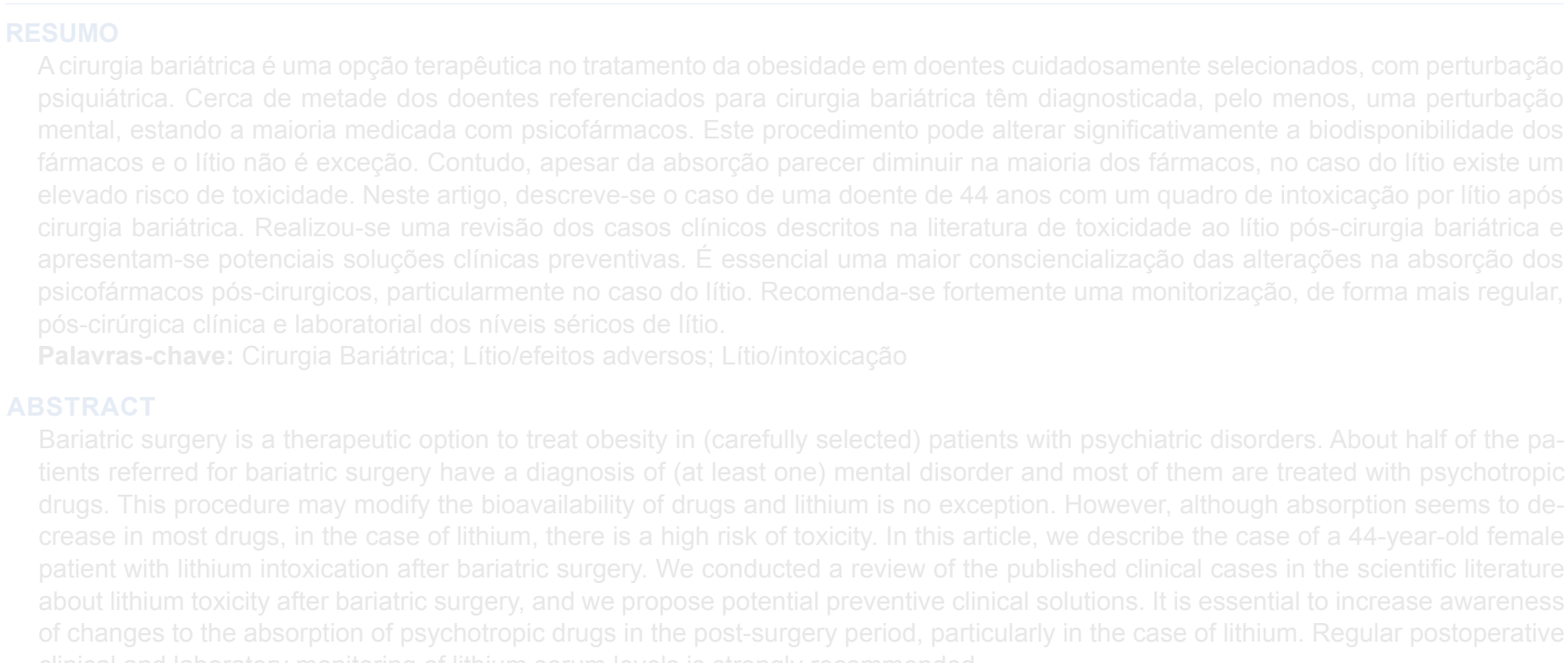

